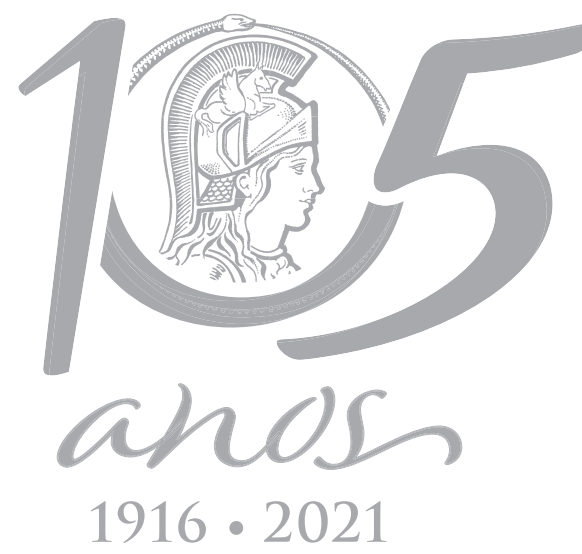

SOCIAL SCIENCES

\title{
Production and profitability of diversified agricultural systems
}

\author{
BRUNO VOLSI, GABRIEL EIJI HIGASHI, IVAN BORDIN \& TIAGO S. TELLES
}

\begin{abstract}
Diversified crop rotation is an option for expanding producer incomes, and its adoption has presented a series of agronomic advantages compared to less diversified crop rotation systems. In this context, the objective of this study was to verify if higherdiversified crop rotation systems perform economically better than low-diversified ones. To this end, we conducted an experiment in no-tillage crop areas in Londrina, in south of Brazil, for the years 2014/15 to 2016/17. The experiment design was randomized blocks, with six treatments, consisting of crop rotation systems with different levels of diversification, and four replications. We observed that higher-diversified crop rotation systems yield higher revenues and profits. Only these systems, specifically the ones that included canola-corn, crambe-corn, and safflower-soybeans, or wheat-corn+brachiaria, canola-corn, and edible beans-soybeans were economically feasible. Despite higher cost, diversified systems with a greater number of commercial crops in winter presented higher profits. However, diversified systems with a high proportion of cover crops in winter are economically infeasible because their net return is negative.
\end{abstract}

Key words: crop rotation, cost analysis, investment analysis, agricultural economy, conservation agriculture.

\section{INTRODUCTION}

In areas planted with temporary crops in Brazil, production systems with less diversification predominate, particularly those where soybeans are grown in the summer followed by corn or wheat grown in the winter, depending on the soil and climate conditions of the production region (Galvão et al. 2014, Freitas \& Mendonça 2016). However, such systems that specialize in only few crops go against what is recommended from a technical-agronomic perspective and what is recommended by conservation agriculture (CA) (Telles et al. 2019, Kassam et al. 2009). Crop systems with less diversification exhibit relative fragility in relation to pests, diseases, weeds, and nematodes, and face conservation challenges related to inadequate soil management, which can result in erosion and decreased organic material (Hunt et al. 2019). In addition, the excessive use of natural resources and agrochemicals in such systems cause soil degradation. As a result, less diversified crop rotation systems are becoming increasingly inefficient and unsustainable, due to stagnation in yields and increasing production costs (Wang et al. 2019).

The CA promotes more diversified production systems based on crop rotation (Cárcer et al. 2019). Such systems can be argued to be the more appropriate agricultural practice when performed continuously, highly diversified crop rotation results in structural and physicalchemical improvements in the soil (Bortoluzzi et al. 2010, Castro et al. 2011) and guarantees soil conservation by controlling soil erosion. Depending on the choice of varieties, the 
sequence of crops adopted, and the duration of plant residues and their effects on the soil, crop rotation increases organic carbon and nitrogen levels in the soil and the quantity of nutrients readily available for the plant and yield stability (Dias et al. 2015, Gaudin et al. 2015). In addition, crop rotation interrupts pest and disease cycles, and in turn reduces the use of chemical products (Selim 2019).

Crops for commercialization should have preferential consideration in crop rotation planning, mainly due to the commercial potential of the grains (Fuentes-Llanillo et al. 2018). In some cases, the crop rotation should also include non-marketed crops whose purpose is soil recovery, such as cover crops (Calegari et al. 2007). Whenever possible the choice should be by regionally adapted cover crops that produce large quantities of dry material and develop rapidly (Machado \& Assis 2010) such as Brachiaria ruziziensis and rye (Oliveira et al. 2019, Rheinheimer et al. 2019). Therefore, crop rotation planning should not always rely exclusively on income-generating crops, given that certain plants instead serve to reduce input costs and generate high yields for subsequent crops (Favarato et al. 2016).

In the state of Paraná, the secondlargest soybean and corn producer in Brazil, less diversified crop rotation systems also predominate. According to the 2017 Agricultural Census, 6.2 million hectares of temporary crops were planted in Paraná, of which 5.2 million hectares were summer soybeans and 2.2 million hectares were winter corn. Northern Paraná, specifically, also hosts production systems with little diversification, which specialize in growing only a few crops that include corn in the winter and soybeans in the summer (Johann et al. 2012).

Highly diversified, no-tillage crop rotation production systems have been recognized from a technical standpoint as a necessary means for successful development of CA (Lal 2015). The concept of CA is based on three principles: minimal soil disturbance, diversified crop species and crop residue for maintenance of a permanent soil cover (Kassam et al. 2019). The CA reduces soil degradation, mitigates the effect of droughts, increase crop productivity, and reduces production costs (Lahmar et al. 2012). In addition, more diversified crop rotation is an alternative for expanding income for grain producers, given that the adoption of other crops into a production system can generate gains when marketed, which consequently reduces some of the economic risk inherent in agriculture (Fontaneli et al. 2000). Nonetheless, producers have adopted production systems with a low degree of crop diversification, presuming that such systems generate greater economic returns, particularly in the short term. (Dury et al. 2012, Volsi et al. 2020).

Despite the well-reported technical benefits regarding highly diversified crop rotation systems (Malézieux et al. 2009), studies that analyze their economic benefits are incipient (Gentry et al. 2012, Grassini et al. 2014, Al-Kaisi et al. 2015, 2016), particularly studies regarding Brazil (Santos et al. 1996, Leal et al. 2005). We hypothesize that with the increase in species diversification, crops will perform better and will become more profitable and economically feasible. Therefore, the objective of this study is to verify if more diversified crop rotation systems perform economically better.

\section{MATERIALS AND METHODS}

The experimental area is located at the headquarters of the Instituto Agronômico do Paraná in the municipality of Londrina, in the state of Paraná, in the south of Brazil (Figure 1). The area is geographically situated at $23^{\circ} 22^{\prime} \mathrm{S}$ 


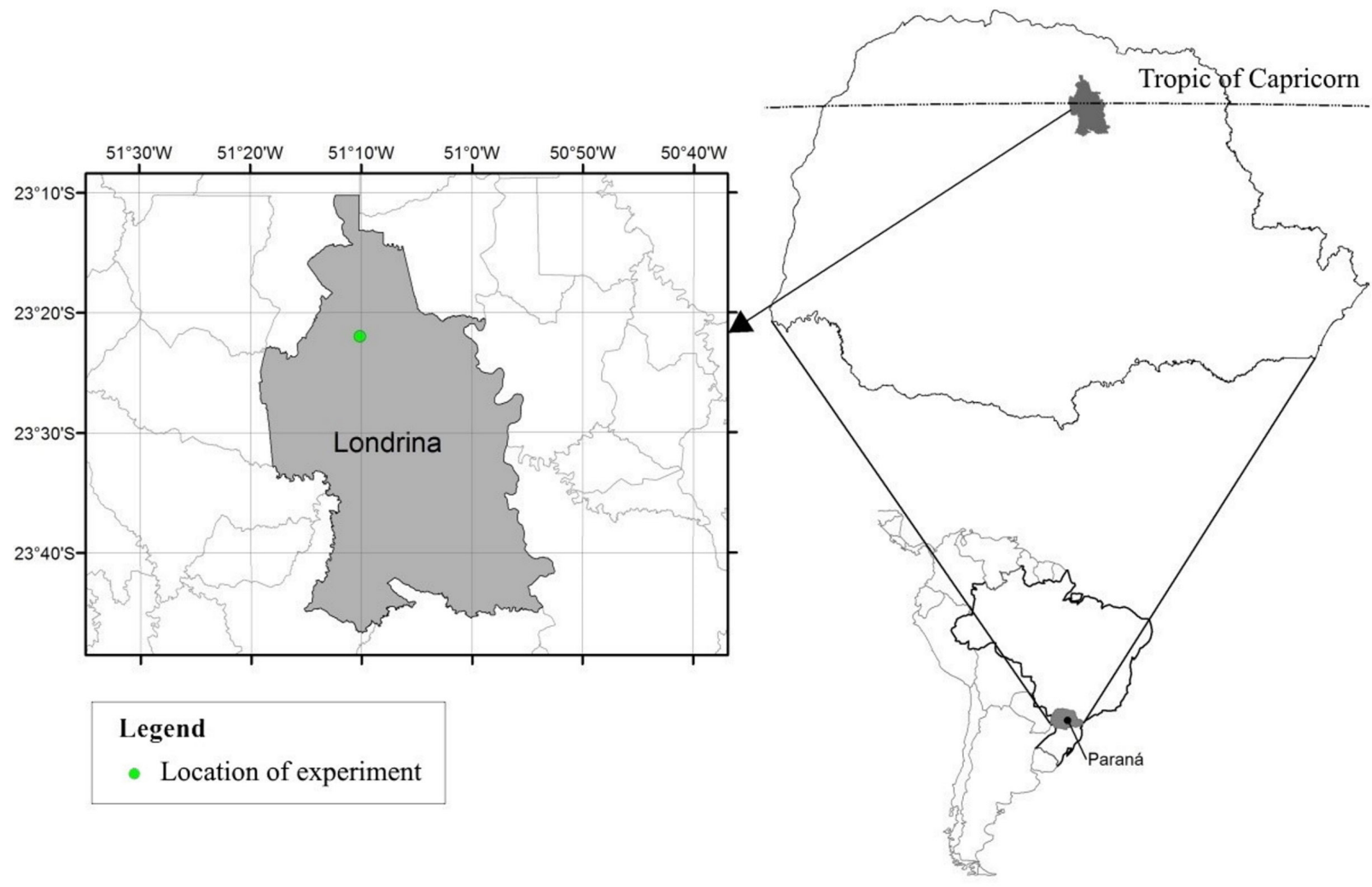

Figure 1. Location of experimental area.

and $51^{\circ} 10^{\prime} \mathrm{W}$, and at an altitude of 585 meters. The soil is classified as a typical eutrophic red latosol, with a clay texture and a mild, undulating relief (Santos et al. 2013).

The climate of the region, according to the Köppen classification, is of type Cfa (humid subtropical), with an average annual temperature of $21.1^{\circ} \mathrm{C}$ and average annual precipitation of approximately $1,523 \mathrm{~mm}$. To reference the climate conditions of the crop years 2014/15 through 2016/17, we calculated the average minimum and maximum temperatures (Figure 2a) and the ten-day water balance (Figure 2b) using spreadsheets from Rolim et al. (1998).

The experiment design involved randomized blocks that included six treatments and four replications. The treatments were composed of six agricultural systems: five highly diversified crop rotation systems and one less diversified crop rotation system, in a three-year cycle (Table
I). The area of each experimental plot was $15 x$ $20 \mathrm{~m}\left(300 \mathrm{~m}^{2}\right.$ ), with a 10-meter spacing between plots to maneuver equipment. Prior to setting up the experiment, the area had served for 11 years as a no-tillage production area, with winter growing of black oats and summer production of alternating corn and soybeans.

Each production system served a distinct purpose. Considering that a diversified system has at least three different crops during the year (Kassam et al. 2019), C-C represented the less diversified crop rotation system. It consists of successive soybean and corn planting and is adopted by the majority of grain producers in northern Paraná. WO-R-W involved a more diverse system in relation to $\mathrm{C}-\mathrm{C}$, where white oats, rye, and wheat took the place of corn as a winter crop in the three years, respectively. To obtain maximum straw cover, O-BO-BR produced oats and rye, black oats and forage 
(a)

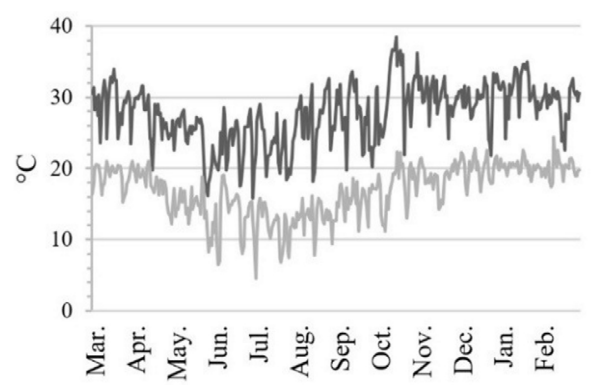

(b)

$2014 / 15$

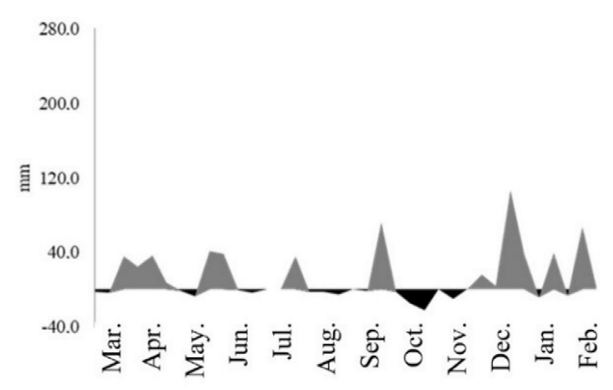

2015/16

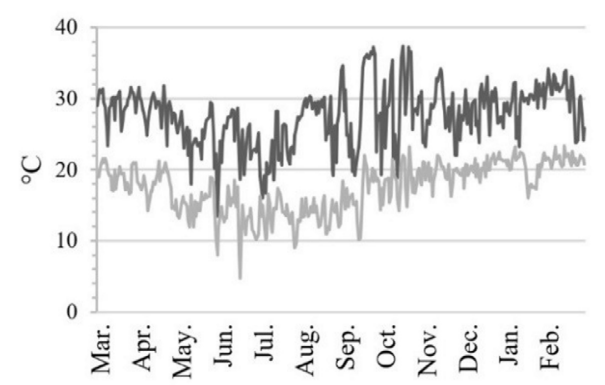

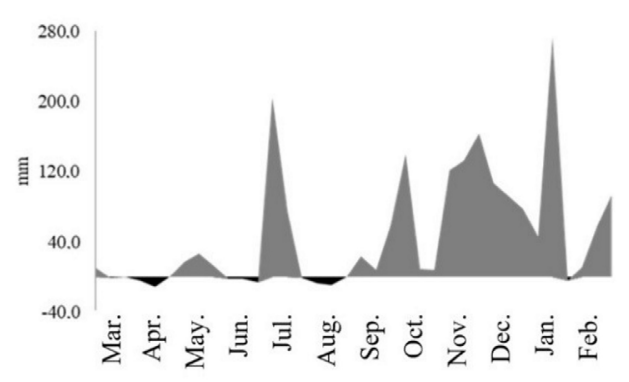

2016/17

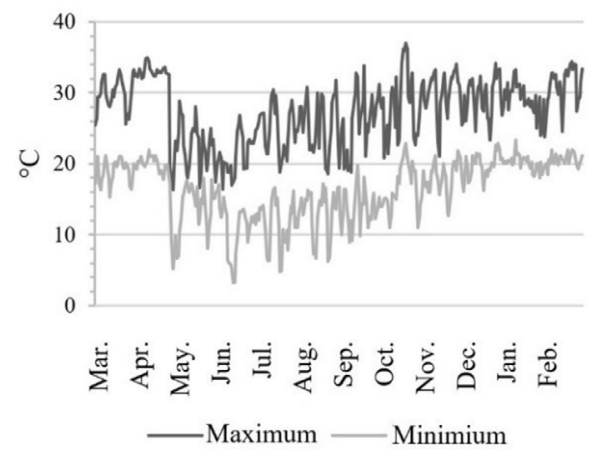

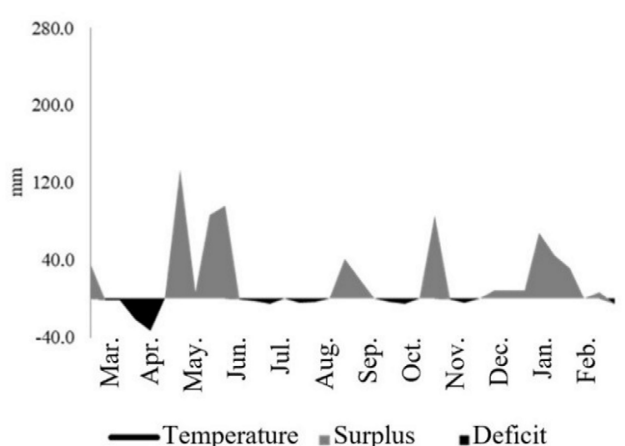

Figure 2. (a)

Minimum and maximum daily temperatures and (b) ten-day water balance (water storage capacity $=80 \mathrm{~mm}$ ), Londrina, Paraná, for the $2014 / 15$ to 2016/17 crop years. Developed based on data from the Instituto Agronômico do Paraná. turnip, and brachiaria grass as the winter crops during the three years, respectively. CL-CR-SF served to produce crops related to agroenergy such as canola, crambe, and safflower, while the winter crops under BW-EB-BW included littlestudied crops with commercial potential such as edible beans and buckwheat. Finally, W-CL-EB presented the greatest crop diversification of all systems, because of the higher numbers of species grown.

To perform the economic analysis, we considered all services and inputs used in each production system. In addition, we calculate the remuneration of capital invested in variable costs and land, indicators for opportunity cost analyses. According to Kay et al. (2014), opportunity cost can be defined as the revenue that could be obtained if the producer invested his money in other activities and rented his property to third. To calculate cost remuneration, we considered an investment with an annual interest rate of $7.5 \%$, and to calculate land renumeration, we used a value of 18 soybeans bags of $60 \mathrm{~kg}$ per hectare, which is the value of land rent used in the region where the experiment took place. To calculate the costs involved in agricultural 
Table I. Crop rotation systems and their respective planting dates, conducted in three-year cycle.

\begin{tabular}{|c|c|c|c|c|c|c|}
\hline \multirow{2}{*}{$\begin{array}{l}\text { Agricultural } \\
\text { system }\end{array}$} & \multicolumn{2}{|c|}{$2014 / 15$} & \multicolumn{2}{|c|}{$2015 / 16$} & \multicolumn{2}{|c|}{ 2016/17 } \\
\hline & Winter & Summer & Winter & Summer & Winter & Summer \\
\hline$C-C$ & $\begin{array}{c}C \\
(19 / 03 / 14)^{1}\end{array}$ & $\begin{array}{c}\mathrm{S} \\
(20 / 10 / 14)\end{array}$ & $\begin{array}{c}C \\
(20 / 03 / 15)\end{array}$ & $\begin{array}{c}\mathrm{S} \\
(07 / 10 / 15)\end{array}$ & $\begin{array}{c}C \\
(14 / 03 / 16)\end{array}$ & $\begin{array}{c}S \\
(10 / 10 / 16)\end{array}$ \\
\hline WO-R-W & $\begin{array}{c}\text { WO } \\
(05 / 05 / 14)\end{array}$ & $\begin{array}{c}S \\
(24 / 10 / 14)\end{array}$ & $\begin{array}{c}R \\
(10 / 04 / 15)\end{array}$ & $\begin{array}{c}C \\
(06 / 10 / 15)\end{array}$ & $\begin{array}{c}W \\
(02 / 05 / 16)\end{array}$ & $\begin{array}{c}S \\
(10 / 10 / 16)\end{array}$ \\
\hline O-BO-BR & $\begin{array}{c}O+R \\
(05 / 05 / 14)\end{array}$ & $\begin{array}{c}S \\
(24 / 10 / 14)\end{array}$ & $\begin{array}{c}\mathrm{BO}+\mathrm{FT} \\
(10 / 04 / 15)\end{array}$ & $\begin{array}{c}C \\
(06 / 10 / 15)\end{array}$ & $\begin{array}{c}\text { BR } \\
(16 / 03 / 16)\end{array}$ & $\begin{array}{c}S \\
(10 / 10 / 16)\end{array}$ \\
\hline CL-CR-SF & $\begin{array}{c}C L \\
(06 / 05 / 14) \\
\end{array}$ & $\begin{array}{c}C \\
(24 / 10 / 14)\end{array}$ & $\begin{array}{c}C R \\
(14 / 04 / 15)\end{array}$ & $\begin{array}{c}C \\
(06 / 10 / 15)\end{array}$ & $\begin{array}{c}\text { SF } \\
(15 / 03 / 16)\end{array}$ & $\begin{array}{c}S \\
(10 / 10 / 16)\end{array}$ \\
\hline BW-EB-BW & $\begin{array}{c}\text { BW/FT } \\
(24 / 03 / 14) \\
(01 / 06 / 14)\end{array}$ & $\begin{array}{c}C \\
(24 / 10 / 14)\end{array}$ & $\begin{array}{c}E B \\
(02 / 04 / 15)\end{array}$ & $\begin{array}{c}S \\
(07 / 10 / 15)\end{array}$ & $\begin{array}{c}\text { BW/O } \\
(14 / 03 / 16) \\
(07 / 07 / 16)\end{array}$ & $\begin{array}{c}S \\
(10 / 10 / 16)\end{array}$ \\
\hline W-CL-EB & $\begin{array}{c}W \\
(05 / 06 / 14)\end{array}$ & $\begin{array}{c}C+B R \\
(24 / 10 / 14)\end{array}$ & $\begin{array}{c}C L \\
(27 / 05 / 15)\end{array}$ & $\begin{array}{c}C \\
(06 / 10 / 15)\end{array}$ & $\begin{array}{c}E B \\
(15 / 03 / 16)\end{array}$ & $\begin{array}{c}S \\
(10 / 10 / 16)\end{array}$ \\
\hline
\end{tabular}

W: wheat. S: soybeans. O: oats. BO: black oats. C: corn. WO: white oats. EB: edible beans. FT: forage turnip. R: rye. CR: crambe. SF: safflower. CL: canola. BW: buckwheat. BR: brachiaria grass. ${ }^{1} T$ he information in parentheses refers to the planting dates of each crop. ' Represents crops grown individually, one after the other.

operations, such as equipment and labor, we considered the area of a medium-scale farm, which represents the majority of rural properties in northern Paraná. According to the Law No. 8,629 (Brasil 1993), in the study region, a medium-scale farm has an area between 48 hectares and 180 hectares.

In our cost analysis, we used costs related to production (i.e. variable costs), following the methodological theory and procedures presented by Kay et al. (2014). To establish the operational costs of seeding, spraying, and harvest, including labor, we used the technical coefficients of the experimental station where the experiment was conducted. The values for agricultural operations (manual and mechanical) and inputs were given in hectares.

To perform an opportunity cost representative of the region where the study was developed and to provide information that would allow for planning and control of future operations for each type of rural activity, we took care with cost records as to not distort data that could serve as a basis for decision-making and activity efficiency analysis. Therefore, to obtain both agricultural operational costs and input costs, we conducted a survey regarding the average values paid and received by producers in the month of June in the years 2014, 2015, and 2016, based on the information obtained from at least three cooperatives and companies from the Londrina region, in Paraná.

For the economic analysis, we used the relation between revenue and cost, or net return, for each production system. We obtained revenues by multiplying production volumes by the respective selling price at harvest. Meanwhile, we obtained yields by weighing the grains harvested from the useful area of the plots, given in $\mathrm{kg} \mathrm{ha}^{-1}$, and by correcting humidity to $13 \%$ on a wet basis (w.b.).

We corrected all economic indicators to December 2019 values using the Extended National Consumer Price Index (IPCA), the 
official inflation index in Brazil, for the purpose of converting nominal values into real values to make comparisons exemplified from effects related to inflation during the study period. The values were converted to US dollars based on the current exchange rate.

\section{RESULTS AND DISCUSSION}

\section{Crop yield}

Table II presents the yield results for each crop rotation system during the three crop years of the experiment. Some moments demonstrated periods of water deficit (Figure 2), which occurred in the summer of 2014/15 between the months of October and November, in the winter of 2015/16 in the months of April and August, and were most pronounced in the winter of 2016/17, between March and April. Water deficits can often limit the growth and development of the plant, particularly when they occur while a plant is flowering or during grain fill (Fioreze et al. 2011, Santos et al. 2012).

An additional factor limiting plant growth and development is low temperatures. Frost, in addition to interfering with the development of the species, can cause plant damage and even mortality (Sereia et al. 2012). During the period under study, we observed only one frost event, in July of 2016/17, with a minimum temperature of $3.2^{\circ} \mathrm{C}$ (Figure $2 \mathrm{a}$ ). Frost damage begins with air temperatures below $3^{\circ} \mathrm{C}$ (Silva \& Sentelhas 2001). During the winter that the frost event in our study occurred, buckwheat, corn, and edible bean yields were, respectively, $32 \%, 58 \%$, and $60 \%$ lower than the average yields for the crops in previous years. In the case of wheat, yields greatly benefitted from the dry and cold weather during this period and were higher that year.

Regarding to soybeans, the highest yields occurred in the 2016/17 crop year, for the most

Table II. Production system yields, for the crop years of 2014/15, 2015/16, and 2016/17.

\begin{tabular}{|c|c|c|c|c|c|c|}
\hline \multirow{2}{*}{$\begin{array}{l}\text { Agricultural } \\
\text { system }\end{array}$} & \multicolumn{2}{|c|}{$2014 / 15$} & \multicolumn{2}{|c|}{$2015 / 16$} & \multicolumn{2}{|c|}{$2016 / 17$} \\
\hline & Winter & Summer & Winter & Summer & Winter & Summer \\
\hline & & - & -_-_- & - & - & \\
\hline \multirow{2}{*}{$C-C$} & C & S & $C$ & S & C & S \\
\hline & 5,895 & 2,965 & 6,536 & 3,241 & 2,737 & 4,030 \\
\hline \multirow{2}{*}{ WO-R-W } & wO & S & $\mathrm{R}$ & C & W & S \\
\hline & 3,247 & 3,518 & - & 9,867 & 3,762 & 4,488 \\
\hline \multirow{2}{*}{$\mathrm{O}-\mathrm{BO}-\mathrm{BR}$} & $\mathrm{O}+\mathrm{R}$ & S & $\mathrm{BO}+\mathrm{FT}$ & $C$ & $\mathrm{BR}$ & S \\
\hline & - & 3,431 & - & 10,300 & - & 4,591 \\
\hline \multirow{2}{*}{$C L-C R-S F$} & $\mathrm{CL}$ & C & $\mathrm{CR}$ & $C$ & SF & S \\
\hline & 1,756 & 11,202 & 1,475 & 9,252 & 1,006 & 4,397 \\
\hline \multirow{2}{*}{ BW-EB-BW } & $\mathrm{BW} / \mathrm{FT}$ & $C$ & $\mathrm{~EB}$ & $\mathrm{~S}$ & $\mathrm{BW}+\mathrm{O}$ & $\mathrm{S}$ \\
\hline & 1,161 & 10,630 & 1,984 & 3,006 & 785 & 4,369 \\
\hline \multirow{2}{*}{ W-CL-EB } & W & $C+B R$ & $\mathrm{CL}$ & C & $\mathrm{EB}$ & S \\
\hline & 1,833 & 10,532 & 1,142 & 9,591 & 776 & 4,617 \\
\hline
\end{tabular}

W: wheat. S: soybeans. O: oats. BO: black oats. C: corn. WO: white oats. EB: edible beans. FT: forage turnip. R: rye. CR: crambe. SF: safflower. CL: canola. BW: buckwheat. BR: brachiaria grass. “-“: no grain production took place. 
diversified crop rotation systems such as that of W-CL-EB $\left(4,617 \mathrm{~kg} \mathrm{ha}^{-1}\right)$, or in systems that practiced the extensive use of cover straw, such as in 0-BO-BR $\left(4,591 \mathrm{~kg} \mathrm{ha}^{-1}\right)$. Meanwhile, the lowest soybean yield was found in the least diversified crop rotation system, C-C $(4,030 \mathrm{~kg}$ $\mathrm{ha}^{-1}$ ), which demonstrated yields that were $12.7 \%$ lower than those observed in W-CL-EB. Other studies also showed that soybean yields from more diversified crop rotation systems were higher than those of crop rotation systems with little diversification (Stanger et al. 2008, Santos et al. 2014). The primary factor in the higher yields found for the last summer under study was the substitution of seeds with highertechnology seeds. Soybeans were the crop least affected by weather complications that summer, presenting an average yield across treatments of approximately 52 bags (60 kg each) per hectare.

\section{Economic analysis}

Table III presents the revenue, variable costs, and net return per hectare for each crop rotation system during the three years of the experiment. We found that the production systems practicing a more diversified crop rotation demonstrated the highest profit and revenue, with the exception of $\mathrm{O}-\mathrm{BO}-\mathrm{BR}$, whose winter crops were used for straw and not marketed. Specifically, we found the best revenue results for W-CL-EB (US\$ 6,466.29), followed by CL-CR-SF (US\$ 5,604.85), WO-R-W (US\$ 5,472.47), BW-EB-BW (US\$ 5,368.47), C-C (US\$ 5,341.72) and O-BO-BR (US\$ 4,380.65).

With respect to variable costs, those of $\mathrm{W}-\mathrm{CL}-$ EB were the highest (US\$ 4,862.14), followed by C-C (US\$ 4,779.43), BW-EB-BW (US\$ 4,526.68), WO-R-W (US\$ 4,486.28), CL-CR-SF (US\$ 4,089.95), and O-BO$\mathrm{BR}$ (US\$3,178.28). Although the quantification and analysis of the variables are extremely important for the decision of the rural producer (Volsi et al. 2020) the variable cost is a relative indicator in the economic analysis, since it is possible to have a high cost that can be more than offset if the revenue is high. One of the issues that can be observed from the analysis of variable costs is to identify which component has the greatest impact. On average, inputs represent the majority of spending, accounted for approximately 53\% of production costs, agricultural operations costs accounted for around 32\%, and other costs, such like taxes, yield transportation and security accounted for around 15\%. In general, in the years when cover crops were grown, the expenditure on inputs was considerably smaller compared to the crops that were commercialized. On average, except for treatment O-BO-BR, all systems had higher input costs in winter than in summer. In relation to the net return, an indicator of the profitability of production systems, W-CLEB performed the best, with a net return of US\$ 1,604.15, followed by CL-CR-SF (US\$ 1,514.90), O-BO-BR (US\$ 1,202.36), WO-R-W (US\$ 985.91), BW-EB-BW (US\$ 841.79), and C-C (US\$ 562.56).

The agricultural systems that showed the best profitability results were those that were most diversified, such as the case of $\mathrm{W}-\mathrm{CL}$ EB and CL-CR-SF - systems that also had the highest revenues and highest variable costs. We should note that a high variable cost does not necessarily imply that the agricultural system is worse; instead, while a production system may present a high variable cost, this may be offset by the revenue the system generates. The crop rotation systems with higher profit were associated, among other factors, with periods of high yields and market prices. In the case of W-CL-EB, as a result of high corn yields in 2015/16, good soybean yields in 2016/17, and of high corn and edible bean prices during the 2015/16 crop year, the production system finished the threeyear period under study with the highest net return. In this case, the market prices positively influenced the net return. The price of agricultural 
Table III. Revenue, variable cost, and net return (US\$ ha-1) of production systems, for the crop years 2014/15, 2015/16, and 2016/17.

\begin{tabular}{|c|c|c|c|c|c|c|c|c|c|}
\hline & \multicolumn{2}{|c|}{$2014 / 15$} & \multicolumn{2}{|c|}{$2015 / 16$} & \multicolumn{2}{|c|}{$2016 / 17$} & \multicolumn{2}{|c|}{ Average } & \multirow{2}{*}{ Cumulative } \\
\hline & Winter & Summer & Winter & Summer & Winter & Summer & Winter & Summer & \\
\hline & \multicolumn{9}{|c|}{$\mathrm{C}-\mathrm{C}$} \\
\hline & C & S & C & S & C & S & & & \\
\hline Revenues & 603.78 & 994.10 & 685.66 & $1,225.57$ & 457.47 & $1,375.42$ & 582.21 & $1,198.27$ & $5,341.72$ \\
\hline Variable cost & 852.44 & 783.11 & 816.13 & 709.20 & 748.44 & 788.84 & 805.76 & 787.47 & $4,779.43$ \\
\hline Inputs & 526.26 & 359.75 & 508.79 & 348.02 & 487.22 & 401.24 & 507.42 & 369.58 & 2.631 .01 \\
\hline Agricultural operations & 220.82 & 307.36 & 201.17 & 316.35 & 171.69 & 254.12 & 197.89 & 292.61 & $1,471.50$ \\
\hline Other costs & 105.63 & 116.28 & 106.18 & 125.83 & 89.53 & 133.47 & 100.45 & 125.29 & 676.93 \\
\hline \multirow[t]{3}{*}{ Net return } & -248.66 & 210.72 & -130.47 & 435.09 & -290.97 & 586.58 & -223.28 & 410.80 & 562.56 \\
\hline & \multicolumn{9}{|c|}{ WO-R-W } \\
\hline & wo & $\mathbf{S}$ & $\mathbf{R}$ & C & $\mathbf{w}$ & $\mathbf{S}$ & & & \\
\hline Revenues & 395.51 & $1,179.44$ & - & $1,757.28$ & 715.41 & $1,424.55$ & 370.40 & $1,453.76$ & $5,472.47$ \\
\hline Variable cost & 560.10 & 766.18 & 464.30 & 967.90 & 945.79 & 781.74 & 656.73 & 838.79 & $4,486.28$ \\
\hline Inputs & 323.18 & 359.75 & 310.90 & 469.21 & 559.28 & 401.24 & 397.69 & 409.98 & $2,423.56$ \\
\hline Agricultural operations & 167.32 & 283.33 & 110.55 & 333.55 & 267.22 & 245.39 & 181.79 & 287.42 & $1,407.35$ \\
\hline Other costs & 69.88 & 123.10 & 42.85 & 165.14 & 119.28 & 135.11 & 77.25 & 141.12 & 655.36 \\
\hline \multirow[t]{3}{*}{ Net return } & -164.59 & 413.25 & -464.30 & 789.38 & -230.37 & 642.81 & -286.33 & 615.24 & 985.91 \\
\hline & \multicolumn{9}{|c|}{ O-BO-BR } \\
\hline & $0+R$ & $\mathbf{S}$ & $\mathrm{BO}+\mathrm{FT}$ & C & BR & $\mathbf{S}$ & & & \\
\hline Revenues & - & $1,150.23$ & - & $1,834.25$ & - & $1,396.16$ & - & $1,460.31$ & $4,380.65$ \\
\hline Variable cost & 235.01 & 779.29 & 192.43 & 976.09 & 204.72 & 791.02 & 210.72 & 848.89 & $3,178.28$ \\
\hline Inputs & 101.27 & 338.19 & 77.52 & 469.21 & 76.15 & 401.24 & 84.89 & 402.88 & $1,463.58$ \\
\hline Agricultural operations & 111.37 & 317.99 & 96.35 & 337.64 & 108.64 & 255.21 & 105.36 & 303.53 & $1,227.20$ \\
\hline Other costs & 22.38 & 123.10 & 18.56 & 169.23 & 19.65 & 134.57 & 20.20 & 142.21 & 487.77 \\
\hline \multirow[t]{3}{*}{ Net return } & -235.01 & 371.22 & -192.43 & 858.17 & -204.72 & 605.14 & -210.72 & 611.42 & $1,202.36$ \\
\hline & \multicolumn{9}{|c|}{ CL-CR-SF } \\
\hline & $\mathrm{CL}$ & C & CR & C & SF & $\mathbf{S}$ & & & \\
\hline Revenues & 577.30 & $1,371.60$ & 252.76 & $1,647.83$ & 292.06 & $1,463.58$ & 373.95 & $1,494.43$ & $5,604.85$ \\
\hline Variable cost & 421.17 & 907.30 & 594.77 & 862.26 & 506.33 & 798.12 & 507.42 & 855.99 & $4,089.95$ \\
\hline Inputs & 209.36 & 498.14 & 326.45 & 443.82 & 296.97 & 401.24 & 277.59 & 447.65 & $2,175.99$ \\
\hline Agricultural operations & 146.30 & 264.77 & 201.99 & 267.50 & 149.03 & 258.49 & 165.68 & 263.67 & $1,288.07$ \\
\hline Other costs & 65.78 & 144.39 & 66.33 & 150.94 & 60.32 & 138.39 & 64.14 & 144.67 & 626.16 \\
\hline \multirow[t]{3}{*}{ Net return } & 155.86 & 464.30 & -341.74 & 785.29 & -214.27 & 665.46 & -133.47 & 638.44 & $1,514.90$ \\
\hline & \multicolumn{9}{|c|}{ BW-EB-BW } \\
\hline & $\mathrm{BW}+\mathrm{FT}$ & C & EB & $\mathbf{S}$ & BW+O & S & & & \\
\hline Revenues & 208.81 & $1,301.72$ & $1,086.91$ & $1,136.58$ & 151.22 & $1,483.24$ & 482.31 & $1,307.18$ & $5,368.47$ \\
\hline Variable cost & 584.12 & 942.79 & 925.59 & 716.78 & 557.37 & 800.30 & 688.94 & 819.96 & $4,526.68$ \\
\hline Inputs & 322.09 & 501.96 & 504.69 & 330.82 & 383.50 & 401.24 & 403.43 & 411.34 & $2,444.04$ \\
\hline Agricultural operations & 198.98 & 296.16 & 286.60 & 270.50 & 115.73 & 259.58 & 200.35 & 275.41 & $1,427.55$ \\
\hline Other costs & 63.33 & 144.39 & 134.57 & 115.46 & 58.14 & 139.48 & 85.43 & 133.20 & 655.36 \\
\hline \multirow[t]{3}{*}{ Net return } & -375.31 & 358.66 & 161.32 & 419.80 & -405.88 & 682.93 & -206.63 & 487.22 & 841.79 \\
\hline & \multicolumn{9}{|c|}{ W-CL-EB } \\
\hline & W & $\mathrm{C}+\mathrm{BR}$ & $\mathrm{CL}$ & C & EB & $\mathbf{S}$ & & & \\
\hline Revenues & 316.63 & $1,289.71$ & 369.31 & $1,708.15$ & $1,322.46$ & $1,460.31$ & 334.10 & $1,429.19$ & $6,466.29$ \\
\hline Variable cost & 564.20 & 910.03 & 472.48 & 877.00 & $1,240.58$ & 797.85 & 759.09 & 861.72 & $4,862.14$ \\
\hline Inputs & 341.19 & 510.15 & 218.36 & 451.47 & 857.90 & 401.24 & 472.48 & 454.20 & $2,780.32$ \\
\hline Agricultural operations & 156.40 & 258.76 & 193.52 & 270.77 & 209.63 & 258.49 & 186.43 & 262.58 & $1,347.03$ \\
\hline Other costs & 66.60 & 141.12 & 60.60 & 154.77 & 173.33 & 138.12 & 100.17 & 144.67 & 734.79 \\
\hline Net return & -247.57 & 379.68 & -103.45 & 831.15 & 81.89 & 662.46 & -89.80 & 624.52 & $1,604.15$ \\
\hline
\end{tabular}

W: wheat. S: soybeans. O: oats. BO: black oats. C: corn. WO: white oats. EB: edible beans. FT: forage turnip. R: rye. CR: crambe. SF: safflower. CL: canola. BW: buckwheat. BR: brachiaria grass. Monetary values corrected with the IPCA to December 2019 values, converted to US\$ dollar. 
products, mainly commodities, suffers from uncertainties regarding the levels of production, local and global demand, issues related to the weather and even with policies such as protection strategies and customs barriers in markets (Godfray et al. 2010). All these factors contribute to the volatility of the market prices. Even though this agricultural system group included Carioca edible beans in the winter of 2016/17 that had the highest variable cost of the entire study (US\$1,240.58), this production system managed to present a net return that was $5.89 \%$ above the next-highest net return. Meanwhile, under CL-CR-SF, the primary factors responsible for high profitability were high market prices for corn during the 2015/16 crop year and high soybean yields in the summer of 2016/17.

O-BO-BR, which presented low revenues and low variable costs, had the third-highest net return (US\$ 1,202.36). As this agricultural system did not aim to market its winter crops, it required fewer inputs to produce the crops within this system, therefore decreasing expenditures for agricultural chemicals and fertilizers. It is important to note that the net revenue was negative in all winters crops. In addition, this system produced only crops for straw cover in winter, aiming to increase yield gains, since straw cover volumes improve soil quality over the long term, reflecting higher summer crop yields and greater operating profit (Leal et al. 2005). Another agronomic benefit related to the adoption of cover crops in crop rotation systems includes the weed population control and suppression of the weed seed bank (Koocheki et al. 2009, Li et al. 2019), reduction in surface soil compaction and an increase in subsequent summer corn and soybean crop yields when adopting cover crops in crop rotation systems (Debiasi et al. 2010).

WO-R-W and BW-EB-BW presented revenues and variable costs that fell in the middle of the results from all agricultural systems. However, despite marketing nearly their entire winter crops, the two systems did not demonstrate the highest profits. Among all the crops adopted within these two systems, white oats, rye, wheat, and buckwheat had variable costs that exceeded their revenues, particularly due to high associated input costs. In the case of WO-R-W, the low yield and high variable cost of white oats in 2014/15, of rye in 2015/16, and of wheat in 2016/17 caused this system to assume fourth place in terms of profitability. The low profitability of BW-EB-BW was attributed to the adoption of buckwheat, which at no time demonstrated satisfactory revenues as a result of its low market value at harvest.

With respect to the less diversified crop rotation systems, $\mathrm{C}-\mathrm{C}$ demonstrated the secondlowest accumulated revenue and the secondhighest variable costs. The net return of this system was 2.8 times less than the highly diversified crop rotation system with the highest net return (W-CL-EB). The variable costs of winter corn in C-C were on average $2.32 \%$ higher than those of soybeans, and the costs for both crops were very close to those found in other studies (Ferreira et al. 2015, Silva et al. 2015). These costs may negatively affect the profitability of the system, since winter crops normally present lower revenues compared to summer crops (Bonjorno et al. 2010). Therefore, the low diversification crop rotation of $\mathrm{C}-\mathrm{C}$ presented the lowest net return. As market uncertainties such as commodity price fluctuations, phytosanitary problems, or adverse weather exist in the agricultural sector, planting crop rotations with little diversification may represent risks for the producer (Ottonelli et al. 2016). In other studies, it was also found that the revenues from more diversified crop rotation systems were higher than those of crop rotations with less diversification (Santos et al. 1999, Goplen et al. 2018). One of the benefits 
of high diversification in crop rotation is the capacity to reduce risk related to agricultural commodity price volatility and the price risk of other cultivars, or to counterbalance low prices through greater crop diversification (Santos et al. 2004, Lehmanna et al. 2013, Castro \& Silva Neto 2018).

Table IV presents annual values for the opportunity costs results of the different agricultural systems. While the results related to net return are important, when we consider opportunity costs such as working capital and land remuneration, our analysis provides an even greater coherent view of the agricultural market.

Therefore, when we considering opportunity costs, the only economically feasible agricultural systems were CL-CR-SF and W-CL-EB. Despite demonstrating positive profits, other production systems - in particular, the least diversified crop rotation, C-C - were not economically feasible. For all agricultural systems, the largest fraction of opportunity cost was land remuneration, as found in Mello \& Esperancini (2015).

As producers in the south of the country have the option of storing grain in silos (specifically at cooperatives), the system for marketing grain in this region has diverged from the marketing process in the rest of the country. This is because producers burden no administrative costs of storing grain in silos during the first year following the soybean or corn harvest. As a result, producers end up having a longer period to make decisions regarding the best moment to sell their product. Thus, while soybeans and corn can be sold at the peak prices of the 12 months directly following harvest, our results may present a different tendency (for better or worse) since the selling price of grain in subsequent years may be higher or lower than the price at harvest. Figure 3 presents the prices per $60-\mathrm{kg}$ bag (US\$) of soybeans and corn during the period of June 2014 to June 2018.

Even if the sale of soybeans and corn had taken place at the peak of prices during the year following harvest, the opportunity costs results of the production systems analyzed in this study would have remained unchanged. Table $\mathrm{V}$ presents what would have been the opportunity costs results in annual values if soybeans and corn had been sold at the peak prices of each quarter of the 12 months following the harvest date.

As shown in Table $V$, only the Treatments CL-CR-SF and W-CL-EB would have been economically feasible; however, they demonstrated cumulative values that were below those found when soybeans and corn were sold immediately after harvest.

This study found a higher profitability of more diversified crop rotation production systems a similar finding to studies conducted in other regions such as the Midwest U.S. (Al-Kaisi et al. 2016), in northeastern China (Fan et al. 2012), in India (Jat et al. 2014), and in Chile (González et al. 2013). All of these results further reinforce the importance of highly diversified crop rotation systems both in terms of their production gains and from an economic perspective.

We note that Brazilian producers have been adopting a production system that is no longer sustainable, neither in terms of economic performance, nor in that, it does not conform environmentally to conservation agriculture. 
Table IV. Opportunity cost and economic profit (US\$ ha-1) of the production systems for the $2014 / 15,2015 / 16$, and 2016/17 crop years.

\begin{tabular}{|c|c|c|c|c|c|}
\hline & $2014 / 15$ & 2015/16 & 2016/17 & Average & Cumulative \\
\hline & \multicolumn{5}{|c|}{$\mathrm{C}-\mathrm{C}$} \\
\hline Agricultural system & C-S & C-S & C-S & & \\
\hline Revenue & $1,597.78$ & $1,911.08$ & $1,832.95$ & $1,780.60$ & $5,341.81$ \\
\hline Variable cost & $1,635.72$ & $1,606.30$ & $1,537.30$ & 1,593.11 & $4,779.33$ \\
\hline Remuneration of production factors & 471.65 & 484.46 & 418.36 & 458.15 & $1,374.46$ \\
\hline \multirow[t]{2}{*}{ Economic profit } & -509.59 & -179.68 & -122.71 & -270.66 & -811.98 \\
\hline & \multicolumn{5}{|c|}{ WO-R-W } \\
\hline Agricultural system & WO-S & $\mathrm{R}-\mathrm{C}$ & W-S & & \\
\hline Revenue & $1,574.93$ & $1,757.25$ & $2,140.20$ & $1,824.13$ & $5,472.38$ \\
\hline Variable cost & $1,326.33$ & $1,432.38$ & $1,727.66$ & $1,495.46$ & $4,486.37$ \\
\hline Remuneration of production factors & 450.61 & 473.21 & 422.62 & 448.81 & $1,346.44$ \\
\hline \multirow[t]{2}{*}{ Economic profit } & -202.01 & -148.34 & -10.08 & -120.14 & -360.43 \\
\hline & \multicolumn{5}{|c|}{ O-BO-BR } \\
\hline Agricultural system & $\mathrm{O}+\mathrm{R}-\mathrm{S}$ & $\mathrm{BO}+\mathrm{FT}-\mathrm{C}$ & BR-S & & \\
\hline Revenue & $1,150.30$ & $1,834.37$ & $1,396.04$ & $1,460.24$ & $4,380.71$ \\
\hline Variable cost & $1,014.09$ & $1,168.56$ & 995.73 & $1,059.46$ & $3,178.37$ \\
\hline Remuneration of production factors & 430.76 & 454.93 & 382.89 & 422.86 & $1,268.59$ \\
\hline \multirow[t]{2}{*}{ Economic profit } & -294.55 & 210.88 & 17.42 & -22.08 & -66.25 \\
\hline & \multicolumn{5}{|c|}{ CL-CR-SF } \\
\hline Agricultural system & $\mathrm{CL}-\mathrm{C}$ & $\mathrm{CR}-\mathrm{C}$ & SF-S & & \\
\hline Revenue & $1,948.80$ & $1,900.50$ & $1,755.59$ & $1,868.29$ & $5,604.89$ \\
\hline Variable cost & $1,328.65$ & $1,456.95$ & $1,304.40$ & $1,363.33$ & $4,090.00$ \\
\hline Remuneration of production factors & 449.49 & 474.37 & 402.73 & 442.19 & $1,326.58$ \\
\hline \multirow[t]{2}{*}{ Economic profit } & 170.66 & -30.82 & 48.46 & 62.77 & 188.31 \\
\hline & \multicolumn{5}{|c|}{ BW-EB-BW } \\
\hline Agricultural system & $\mathrm{BW}+\mathrm{FT}-\mathrm{C}$ & EB-S & $\mathrm{BW}+\mathrm{O}-\mathrm{S}$ & & \\
\hline Revenue & $1,510.53$ & $2,223.47$ & $1,634.50$ & $1,789.50$ & $5,368.50$ \\
\hline Variable cost & $1,526.97$ & $1,642.35$ & $1,357.48$ & $1,509.21$ & $4,526.80$ \\
\hline Remuneration of production factors & 464.55 & 485.81 & 406.78 & 452.38 & $1,357.15$ \\
\hline \multirow[t]{2}{*}{ Economic profit } & -481.00 & 95.30 & -129.76 & -171.82 & -515.46 \\
\hline & \multicolumn{5}{|c|}{ W-CL-EB } \\
\hline Agricultural system & $W-C+B R$ & $C L-C$ & EB-S & & \\
\hline Revenue & $1,606.22$ & $2,077.27$ & $2,782.88$ & $2,155.46$ & $6,466.37$ \\
\hline Variable cost & $1,474.15$ & $1,349.58$ & $2,038.48$ & $1,620.74$ & $4,862.22$ \\
\hline Remuneration of production factors & 460.60 & 466.43 & 449.32 & 458.78 & $1,376.35$ \\
\hline Economic profit & -328.54 & 261.26 & 295.09 & 75.94 & 227.81 \\
\hline
\end{tabular}

W: wheat. S: soybeans. O: oats. BO: black oats. C: corn. WO: white oats. EB: edible beans. FT: forage turnip. R: rye. CR: crambe. SF: safflower. CL: canola. BW: buckwheat. BR: brachiaria grass. Monetary values corrected with the IPCA to December 2019 values, converted to US\$ dollar. 


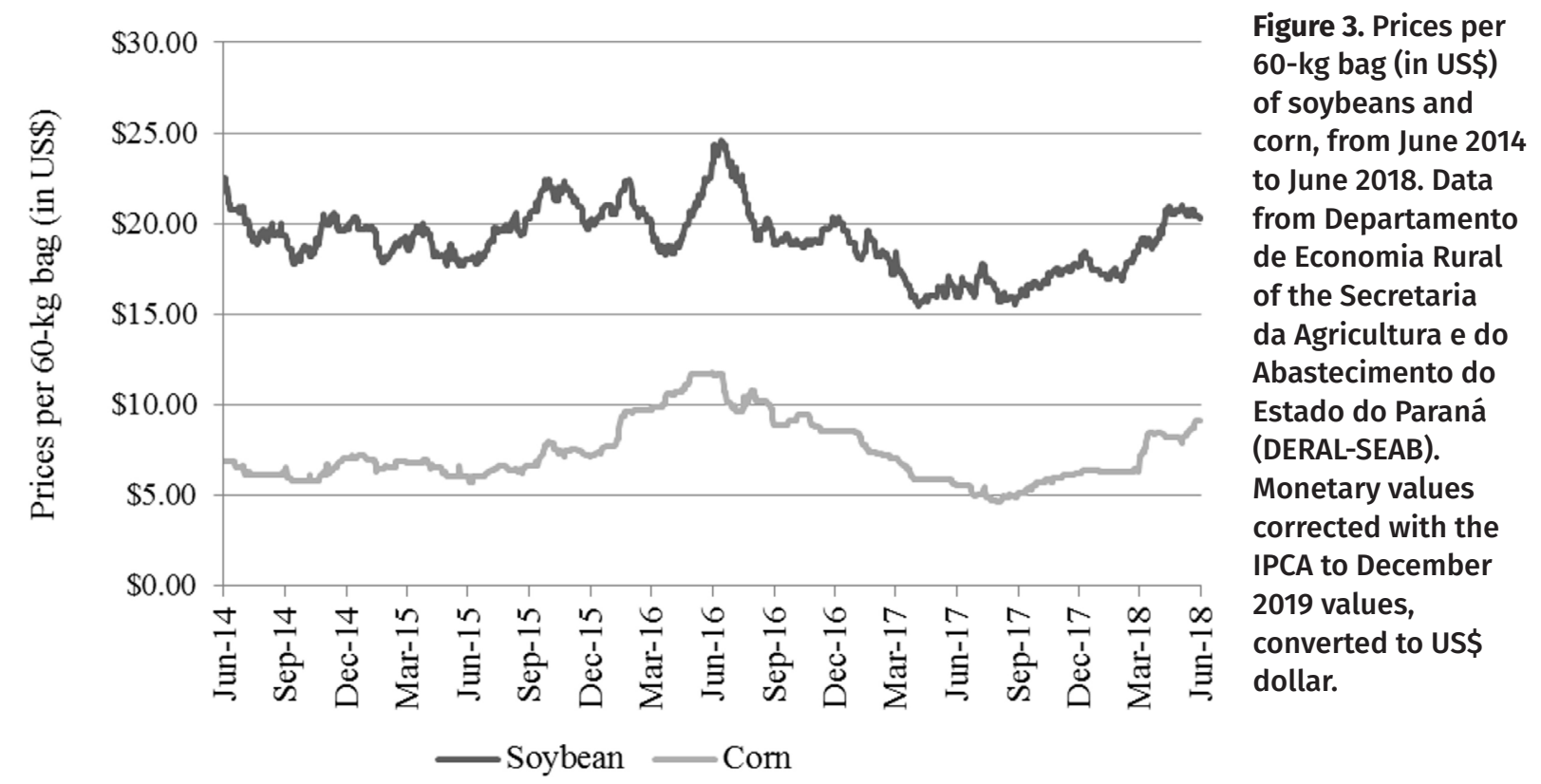

Table V. Opportunity costs (US\$ ha-1) of each production system for the 2014/15, 2015/16, and 2016/17 crop years, assuming peak quarterly prices.

\begin{tabular}{|c|c|c|c|c|c|}
\hline Agricultural system & $\mathbf{2 0 1 4 / 1 5}$ & $\mathbf{2 0 1 5 / 1 6}$ & $\mathbf{2 0 1 6 / 1 7}$ & Average & Cumulative \\
\hline C-C & -368.97 & 230.59 & -392.33 & -176.90 & -530.71 \\
\hline WO-R-W & -138.28 & -192.93 & -83.65 & -138.29 & -414.86 \\
\hline O-BO-BR & -232.44 & 164.33 & 3.61 & -21.50 & -64.50 \\
\hline CL-CR-SF & 263.97 & -72.65 & -91.24 & 33.36 & 100.08 \\
\hline BW-EB-BW & -392.70 & 68.67 & -297.66 & -207.23 & -621.68 \\
\hline W-CL-EB & -240.93 & 218.05 & 224.72 & 67.28 & 201.84 \\
\hline
\end{tabular}

Monetary values corrected with the IPCA to December 2019 values, converted to US\$ dollar.

\section{CONCLUSIONS}

Diversified crop rotation systems perform economically better. Increasing diversity in crop rotation systems favors profitability and feasibility compared to less diversified systems, such as corn-soybean. Despite the higher cost, diversified systems with a higher number of commercial crops in winter presented higher profits. However, diversified systems with a high proportion of cover crops in winter are economically infeasible because their net return is negative.

Thus, our results demonstrated the economic differences between highly and less diversified crop rotation systems. The benefits of more diversified crop rotation systems are significant for agriculture, affecting production, the cost-benefit of agricultural production, and opportunity costs. 


\section{Acknowledgments}

The authors acknowledge the financial support received from Conselho Nacional de Desenvolvimento Científico e Tecnológico - CNPq (315529/2020-2, 429050/2016-0), and Coordenação de Aperfeiçoamento de Pessoal de Nivel Superior - CAPES.

\section{REFERENCES}

AL-KAISI M, ARCHONTOULIS S \& KWAW-MENSAH D. 2016. Soybean spatiotemporal yield and economic variability as affected by tillage and crop rotation. Agron J 108: 1267-1280.

AL-KAISI M, ARCHONTOULIS S, KWAW-MENSAH D \& MIGUEZ F. 2015. Tillage and crop rotation effects on corn agronomic response and economic return at seven lowa locations. Agron J 107: 1411-1424.

BONJORNO II, MARTINS LAO, LANA MA, BITTENCOURT HVH, WILDNER LP, PARIZOTTO C, FAYAD JA, COMIN JJ, ALTIERI MA \& LOVATO PE. 2010. Efeito de plantas de cobertura de inverno sobre cultivo de milho em Sistema de plantio direto. Rev Bras Agroecol 5: 99-108.

BORTOLUZZI EC, POLETO C, BAGINSKI ÁJ \& SILVA VR. 2010. Aggregation of subtropical soil under liming: a study using laser diffraction. Rev Bras Ciên Solo 34: 725-734.

BRASIL. 1993. Law 8.629 of February 25. Available on <https:// www2.camara.leg.br/atividade-legislativa>. Accessed: Feb. 10, 2020.

CALEGARI A, COSTA A \& RALISCH R. 2007. Sustainable agriculture with no-tillage including cover crops and crop rotation. Ann Arid Zone 46: 1-23.

CÁRCER OS, SINAJ S, SANTOJA M, FOSSATI D \& JENAGROS B. 2019. Long-term effects of crop succession, soil tillage and climate wheat yield and soil properties. Soil Till Res 190: 209-219.

CASTRO GSA, CALONEGO JC \& CRUSCIOL CAC. 2011. Propriedades físicas do solo em sistemas de rotação de culturas conforme o uso de corretivos da acidez. Pesqui Agropecu Bras 46: 1690-1698.

CASTRO MC \& SILVA NETO WA. 2018. Risco na variação de preços agropecuários: evidências empíricas para os mercados de soja, milho e boi gordo em Rio Verde, Goiás. Rev Econ Nordeste 49: 83-97.

DEBIASI H, LEVIEN R, TREIN CR, CONTEE O \& KAMIMURA KM. 2010. Produtividade de soja e milho após coberturas de inverno e descompactação mecânica do solo. Pesqui Agropecu Bras 45: 603-612.
DIAS T, DUKES A \& ANTUNES PM. 2015. Accounting for soil biotic effects on soil health and crop productivity in the design of crop rotations. J Sci Food Agric 95: 447-454.

DURY J, SCHALLER N, GARCIA F, REYNAUD A \& BERGEZ JE. 2012. Models to support cropping plan and crop rotation decisions. A review. Agron Sustain Dev 32: 657-580.

FAN R, ZHANG X, LIANG A, SHI X, CHEN X, BAO K, YANG X \& JIA S. 2012. Tillage and rotation effects on crop yield and profitability on a Black soil in northeast China. Can J Soil Sci 92: 463-470.

FAVARATO LF, SOUZA JL, GALVÃO JCC, SOUZA CM, GUARCONI RC \& BALBINO JMS. 2016. Crescimento e produtividade do milhoverde sobre diferentes coberturas de solo no sistema plantio direto orgânico. Bragantia 75: 497-506.

FERREIRA BGC, FREITAS MML \& MOREIRA GC. 2015. Custo operacional efetivo de produção de soja em sistema plantio direto. iPecege 1: 39-50.

FIOREZE SL, PIVETTA LG, FANO A, MACHADO FR \& GUIMARÃES VF. 2011. Comportamento de genótipos de soja submetidos a déficit hídrico intenso em casa de vegetação. Rev Ceres 58: 342-349.

FONTANELI RS, AMBROSI I, SANTOS HP, IGNACZAK JC \& ZOLDAN SM. 2000. Análise econômica de sistemas de produção de grãos com pastagens anuais de inverno, em sistema plantio direto. Pesqui Agropecu Bras 35: 2129-2137.

FREITAS RE \& MENDONÇA MAA. 2016. Expansão agrícola no brasil e a participação da soja: 20 anos. Rev Econ Sociol Rural 54: 497-516.

FUENTES-LLANILLO R, TELLES TS, VOLSI B, SOARES JÚNIOR D, CARNEIRO SL \& GUIMARÃES MF. 2018. Profitability of no-till grain production systems. Semin Cienc Agrar 39: 77-86.

GALVÃO JCC, MIRANDA GV, TROGELLO E \& FRITSCHE-NETO R. 2014. Sete décadas de evolução do sistema produtivo da cultura do milho. Rev Ceres 61: 819-828.

GAUDIN ACM, TOLHURST TN, KER AP, JANOVICEK K, TORTORA C, MARTIN RC \& DEEN W. 2015. Increasing crop diversity mitigates weather variations and improves yield stability. PLOS ONE 10: e0113261.

GENTRY LF, RUFFO ML \& BELOW FE. 2012. Identifying factors controlling the continuous corn yield penalty. Agron J 105: 295-303.

GODFRAY HCJ, BEDDINGTON JR, CRUTE IR, HADDAH L, LAWRENCE D, MUIR JF, PRETTY J, ROBINSON S, THOMAS SM \& TOULMIN C. 2010. Food security: the challenge of feeding 9 billion people. Science 327: 812-818. 
GONZÁLEZ JU, UNDURRAGA P, HIRZEL J \& MARTÍNEZ GI. 2013. Economic evaluation of a crop rotation portfolio for irrigated farms in central Chile. Chil J Agr Res 73: 243-249.

GOPLEN JJ, COULTER JA, SHEAFFER CC, BECKER RL, BREITENBACH FR, BEHNKEN LM \& GUNSOLUS JL. 2018. Economic performance of crop rotations in the presence of herbicide-resistant giant ragweed. Agron J 110: 260-268.

GRASSINI P, TORRION JA, GASSMAN KG, YANG HS \& SPECHT JE. 2014. Drivers of spatial and temporal variation in soybean yield and irrigation requirements in western US Corn Belt. Field Crop Res 163: 32-46.

HUNT ND, HILL JD \& LIEBMAN M. 2019. Cropping system diversity effects on nutrient discharge, soil erosion, and agronomic performance. Environ Sci Technol 53: 1344-1352.

JAT RK, SAPKOTA TB, SINGH RG, JAT ML \& KUMAR M. 2014. Seven years of conservation agriculture in a rice-wheat rotation of Eastern Gangetic Plains of South Asia: Yield trends and economic profitability. Field Crop Res 164: 199-210.

JOHANN JA, ROCHA JV, DUFT DG \& LAMPARELLI RAC. 2012. Estimativa de áreas com culturas de verão no Paraná, por meio de imagens multitemporais EVI/Modis. Pesqui Agropecu Bras 47: 1295-1306.

KASSAM A, FRIEDRICH T \& DERPSCH R. 2019. Global spread of conservation agriculture. Int J Environ Stud 76: 29-51.

KASSAMA, FRIEDRICH T, SHAXSON F \& PRETTY J. 2009. The spread of Conservation Agriculture: justification, sustainability and uptake. Int J Agr Sustain 7: 292-320.

KAY RD, EDWARDS WM \& DUFFY PA. 2014. Gestão de propriedades rurais. $7^{\text {th }}$ Ed., Porto Alegre: AMGH, 452 p.

KOOCHEKI A, NASSIRI M, ALIMORADI L \& GHORBANI R. 2009. Effect of cropping systems and crop rotations on weeds. Agron Sustain Dev 29: 401-408.

LAHMAR R, BATIONO BA, LAMSOC ND, GUÉRO Y \& TITTONELL P. 2012. Tailoring conservation agriculture technologies to West Africa semi-arid zones: Building on traditional local practices for soil restoration. Field Crops Res 132: 158-167.

LAL L. 2015. A system approach to conservation agriculture. J Soil Water Conserv 70: 82A-88A.

LEAL AJF, LAZARINI E, TARSITANO MAA, SÁ ME \& GOMES JÚNIOR FG. 2005. Viabilidade econômica da rotação de culturas e adubos verdes antecedendo o cultivo do milho em sistema de plantio direto em solo de cerrado. Rev Bras Milho Sorgo 4: 298-307.

LEHMANNA N, BRINERA S \& FINGERB R. 2013. The impact of climate and price risks on agricultural land use and crop management decisions. Land Use Policy 35: 119-130.
LI J, HUANG L, ZHANG J, COULTER JA, LI L \& GAN Y. 2019. Diversifying crop rotation improves system robustness. Agron Sustain Dev 39: 38.

MACHADO LAZ \& ASSIS PGG. 2010. Produção de palha e forragem por espécies anuais e perenes em sucessão à soja. Pesqui Agropecu Bras 45: 415-422.

MALÉZIEUX E, CROZAT Y, DUPRAZ C, LAURANS M, MAKOWSKI D, OZIERLAFONTAINE H, RAPIDEL B, TOURONNET S \& VALANTINMORISON M. 2009. Mixing plant species in cropping systems: concepts, tools and models. A review. Agron Sustain Dev 29: 43-62.

MELLO DA \& ESPERANCINI MST. 2015. Avaliação econômica do cultivo da soja em rotação e sucessão de culturas: resultados a partir de estudo de caso no município de Ourinhos/SP, na safra 2012/13. Energ Agric 30: 280-288.

OLIVEIRA SM, ALMEIDA REM, PIEROZAN JUNIOR C, REIS AFB, SOUZA LFN \& FAVARIN JL. 2019. Contribution of corn intercropped with Brachiaria species to nutrient cycling. Pesq Agropec Trop 45: e55018.

OTTONELLI J, GRINGS TC \& CERETTA PS. 2016. Impacto de fatores de mercado nos retornos de preços agrícolas. Organ Rurais Agroind 18: 228-237.

RHEINHEIMER DS, FORNARI MR, BASTOS MR, FERNANDES G, SANTANNA MA, CALEGARI A, CANALLI LBS, CANER L, LABANOWSKI J \& RIECHER T. 2019. Phosphorus distribution after three decades of different soil management and cover crops in subtropical region. Soil Tillage Res 192: 33-41.

ROLIM GS, SENTELHAS PC \& BARBIERI V. 1998. Planilhas no ambiente Excel TM para os cálculos de balanços hídricos: normal, sequencial, de cultura e de produtividade real e potencial. Rev Bras Agrometeorol 6: 133-137.

SANTOS HG. 2013. Sistema Brasileiro de Classificação de Solos, $3^{\text {rd }}$ Ed., Brasília: Embrapa Solos, 353 p.

SANTOS HP, AMBROSI I, IGNACZAK JC \& SANDINI I. 1996. Análise econômica de sistemas de rotação de culturas para ceva, sob sistema plantio direto. Pesqui Agropecu Bras 31: 165-171.

SANTOS HP, AMBROSI I \& LHAMBY JCB. 1999. Análise de risco em quatro sistemas de rotação de culturas para trigo, num período de dez anos, em Passo Fundo, RS. Pesqui Agropecu Bras 34: 519-526.

SANTOS HP, AMBROSI I, LHAMBY JCB \& CARMO C. 2004. Lucratividade e risco de sistemas de manejo de solo e de rotação e sucessão de culturas. Cienc Rural 34: 97-103.

SANTOS HP, FONTANELI RS, PIRES J, LAMPERT EA, VARGAS AM \& VERDI AC. 2014. Grain yield and agronomic traits in 
soybean according to crop rotation systems. Bragantia 73: 263-273.

SELIM MM. 2019. A review of advantages, disvantages and challenges of crop rotations. Egypt J Agron 44: 1-10.

SEREIA RC, LEITE LF, ALVES VB \& CECCON G. 2012. Crescimento de Brachiaria spp. e milho safrinha em cultivo consorciado. Agrarian 5: 349-355.

SILVA JG \& SENTELHAS PC. 2001. Diferença de temperatura mínima do ar medida no abrigo e na relva e probabilidade de sua ocorrência em eventos de geada no Estado de Santa Catarina. Rev Bras Agrometeorol 9: 9-15.

SILVA WL, DERECZYNSKI C, CHANG M, FREITAS M, MACHADO BJ, TRISTÃO L \& RUGGERI J. 2015. Tendências observadas em indicadores de extremos climáticos de temperatura e precipitação no estado do Paraná. Rev Bras Meteorol 30: 181-194.

STANGER TF, LAUER JG \& CHAVAS JP. 2008. The profitability and risk of long term cropping systems featuring different rotations and nitrogen rates. Agron J 100: 105-113.

TELLES TS, LOURENÇO MAP, OLIVEIRA JF, COSTA GV \& BARBOSA GMC. 2019. Soil conservation practices in a watershed in Southern Brazil. An Acad Bras Cienc 91: e20180578.

VOLSI B, BORDIN I, HIGASHI GE \& TELLES TS. 2020. Economic profitability of crop rotation systems in the Caiuá sandstone area. Cienc Rural 50: 2.

WANG T, JIN H, KASU BB, JACQUET J \& KUMAR S. 2019. Soil conservation practice adoption in the Northern Great Plains: Economic versus stewardship motivations. J Agr Resour Econ 44: 404-421.

\section{How to cite}

VOLSI B, HIGASHI GE, BORDIN I \& TELLES TS. 2021. Production and profitability of diversified agricultural systems. An Acad Bras Cienc 93: e20191330. DOI 10.1590/0001-3765202120191330.
Manuscript received on October 29, 2019;

accepted for publication on March 20, 2020

\section{BRUNO VOLSI ${ }^{1}$}

https://orcid.org/0000-0001-9820-0585

\section{GABRIEL EIJI HIGASHI}

https://orcid.org/0000-0003-3538-4131

\section{IVAN BORDIN ${ }^{2}$}

https://orcid.org/0000-0002-4904-6283

\section{TIAGO S. TELLES ${ }^{2}$}

https://orcid.org/0000-0001-5817-3420

${ }^{1}$ Universidade Estadual de Londrina, Departamento

de Agronomia, Rodovia Celso Garcia Cid, Km

380, 86057-970 Londrina, PR, Brazil

${ }^{2}$ Instituto de Desenvolvimento Rural do Paraná, IAPAR-EMATER, Rodovia Celso Garcia Cid, Km

375, 86047-902 Londrina, PR, Brazil

Correspondence to: Tiago S. Telles

E-mail:telles@idr.pr.gov.br

\section{Author contributions}

IB and TST conceived the study conceptualization. BV, GEH and TST conducted the data curation, methodology, formal analysis, and writing, review and editing. IB and TST performed the project administration. All authors reviewed the manuscript.

\section{(cc) BY}

